\title{
FIMA Holistic Approach to the HIV/AIDS Pandemic
}

\author{
Aly A. Misha'l MD, FACP \\ Chairman FIMA Committee on Bioethics \\ Senior Consultant in Endocrinology \\ Chief of Medical Staff \\ Islamic Hospital \\ Amman, Jordan
}

\begin{abstract}
The human immunodeficiency virus (HIV) is transmitted predominantly by promiscuous heterosexual and homosexual relations, from mother to child, and through drug abuse and transfusion of blood products.

Worldwide efforts to prevent the spread of HIV and the acquired immune deficiency syndrome (AIDS) pandemic have been disappointing.

The Islamic approach, adopted by organizations working under the umbrella of the Federation of Islamic Medical Associations (FIMA), is a holistic system of prevention, treatment, care, and support to combat the spread of the pandemic and to limit its deleterious health, psychosocial, and economic consequences.

This paper outlines this holistic approach.
\end{abstract}

Key words: HIV/AIDS, HIV transmission, sexual morality, drug abuse, Islam.

A s of 2008 , it is estimated that 33 million people are living with human immunodeficiency virus (HIV) or acquired immune deficiency syndrome (AIDS), making it one of the worst pandemics. African nations are particularly hard hit. Although only $11 \%$ of the world population lives in Africa, more than $60 \%$ of the people infected with HIV or AIDS worldwide are concentrated there, especially in the sub-Saharan countries.

In 2007, more than 2 million people died of AIDS. More than half of these are in the 15-25-year-old age group, which is the main work force demographic, creating a great social and economic significance..$^{1-5}$

Modes of HIV transmission have not changed over the past 25 years. They include transmission through homosexual and heterosexual relations, intravenous drug abuse, transfusion with contami-

Correspondence should be directed to

info@islamic-hospital.org nated blood, and transmission from mother to child during labor or breast-feeding. ${ }^{1-5}$ Overall, promiscuous sexual behavior is the predominant mode of HIV transmission. ${ }^{6}$

Because homosexuality, promiscuous heterosexual sex, and drug abuse are strictly forbidden (haram) in Islam, it has been assumed that HIV/AIDS cannot penetrate Muslim communities. However, this thought has proven to be false. In countries where Muslims are the minority, HIV/AIDS is affecting Muslims, as well as non-Muslims. In countries where Muslims are the majority, there is overwhelming evidence suggesting that a significant proportion of Muslim populations, especially the youth, are engaged in lifestyles and activities that ultimately can lead to contracting HIV/AIDS and other sexually transmitted infections (STIs). ${ }^{6}$

Over the past decade, STIs, particularly HIV/AIDS, became a center of concern and action in the framework of activities of the Federation of Islamic Medical Associations (FIMA). Some of the 
Islamic medical associations, namely those in Uganda and South Africa, classified this growing dilemma a major priority even before that.7-10

The Federation of Islamic Medical Associations decided on a prevention strategy that involved combating HIV/AIDS holistically, taking in consideration that it is not just a virus-induced epidemic, but a manifestation of a serious breakdown of socio-moral and behavioral standards that invaded societies at variable degrees all over the world. At the same time, the FIMA strategy did not neglect the social, moral, and medical care of affected people.

The FIMA approach to healthcare adopts a holistic medical model, which it considers superior to the Western biomedical model, whose main drawback is its narrow focus, inflexibility, materialistic approaches, and marginalization of spiritual, cultural, lifestyle, and psychosocial factors. This model has been disappointing in combating HIV/AIDS and other STIs, as well as many other lifestyle-related medical dilemmas.

The serious limitations of the Western biomedical model in dealing with the HIV/AIDS pandemic cannot be overcome until its philosophical background is re-examined. The proper approach should take in consideration the spiritual, behavioral and psychosocial aspects of health, lifestyle, environmental amelioration, health promotion, disease prevention, and minimization of profit motives. ${ }^{11-15}$

The Federation of Islamic Medical Associations has embarked on several activities to combat the HIV/AIDS pandemic, which may vary from one society to another, but together represent a complete system of care and prevention, using religious, moral, and up-to-date medical standards.

The following concise account describes the main activities performed by FIMA, its member Islamic medical associations, and collaborating concerned organizations in different regions of the world.

\section{FIMA Activities to Combat HIV/AIDS in Africa and Asia}

\section{In Africa}

The Islamic Medical Association of Uganda (IMAU), a FIMA member, has played a leading role since 1989.8-10 It started an initiative now called International Muslim Leaders' Consultations on HIV/AIDS (IMLCs). During these consultations
Muslim leaders in their various capacities as health professionals, religious leaders, women and youth leaders, and leaders in government and nongovernmental organizations gather to share experiences of the Islamic approach to HIV/AIDS. The first IMLC was held in Kampala, Uganda, in November 2001. During this consultation, and at a later FIMA council meeting, it was decided that a center for promotion of the Islamic approach to HIV/AIDS would be established in Kampala. Another resolution was made to lobby the Organization of the Islamic Conference (OIC) to establish or designate a department or a desk for promoting the Islamic approach to HIV/AIDS prevention and control.

The second IMLC was held in Kuala Lumpur, Malaysia, in May 2003.

The third International Muslim Leaders' Consultation on HIV/AIDS was held in Addis Ababa on July $23-27,2007$, with participants from 28 countries. The conference promoted understanding and use of the Islamic approach to HIV/AIDS. Issues discussed included the following:

- Enhancing the community response: What imams and mosque communities can do.

- Training guidelines for imams, community educators, and mosque communities.

- Interfaith dialogue and collaboration.

The following are the main features of the adopted Islamic approach to HIV/AIDS, which form the basis of leaders/workers training, as well as community- and country-proposed plans of action:

1. A spiritual and belief system that comprises Islamic teachings and guidance to mankind and promotes sound ethical behavior and lifestyle, which provide sound guidelines for preventing HIV/AIDS and other STIs. Also stressed are the Islamic guidelines advocating seeking medical treatment and the duty of society to care, support, and abolish discrimination and stigmatization of disease victims.

2. Scientific knowledge about HIV/AIDS and other STIs includes causative organisms, epidemiology, world experience, mode of spread, prevention, and treatment. This includes proper use of condoms as a means of disease prevention and not as means of encouraging unethical, uncondoned sexual relations.

3. Forming partnerships and collaboration relationships with religious and community leaders to deliver sound education and counseling to the widest 
sectors of grassroots communities, aiming at promotion of ethical and sound behaviors, encouraging timely marriage, and avoiding adultery, alcohol, and drug abuse.

In addition, FIMA has set up an HIV/AIDS committee to assist in organizing its activities in this area. It was initiated and will operate as the International Center for Promotion of the Islamic Approach to HIV/AIDS in Kampala. The offices have already been constructed under the supervision of the IMAU. The overall goal is to use Islamic principles and guidelines to prevent and control HIV infection.

\section{Objectives}

1. To establish a functional International Center for coordination, advocacy, and promotion of the Islamic approach to HIV/AIDS prevention, treatment, care, and support for the benefit of all communities.

2. To establish demonstration project sites and resource centers that are using the Islamic approach to HIV/AIDS prevention, treatment, care, and support.

3. To establish a network through which to share experiences, facilitate training of personnel, build organizational capacity, and develop common policy guidelines and strategic plans for the promotion of the Islamic approach to HIV/AIDS prevention, treatment, care, and support among all stakeholders. This includes establishing appropriate linkages with concerned international and regional organizations.

4. To conduct research and disseminate findings on various aspects of the Islamic approach to HIV/AIDS prevention, treatment, care, and support.

5. To document, disseminate, and share experiences of the Islamic approach to HIV/AIDS prevention, treatment, care, and support with all stakeholders, including other faith-based organizations and other organizations fighting the AIDS pandemic.

Since 1998 the Islamic Medical Association of South Africa, a FIMA member, has adopted a HIV/AIDS prevention program under the Muslim AIDS Program (MAP)10,13 and in collaboration with two other Muslim organizations, Jamiatul Ulama and the Islamic Careline (sisters in a counseling service). The program has gained ground in most major provinces in South Africa, with constructive cooperation and understanding by the health authorities of the South African government.

Since 1998, community awareness, life skills school programs, volunteer training, capacity building, home-based care, and orphan and vulnerable children programs have been ongoing.

Another program, the Muslim AIDS Program Care Center was established in July 2003. It accommodates women and children infected with or affected by HIV/AIDS. The two dimensions of action have been:

1. Prevention: In order to prevent infection, we need to comply with Islamic injunctions. Islam has the cure.

2. Care of those unfortunate individuals who became infected. Increased levels of spirituality that draw people close to their Creator, His mercy, and forgiveness, go hand-in-hand with medical and social care. Stigmatization is properly avoided according to Islamic guidelines of caring for the infected and affected individuals.

\section{In Southeast Asia}

Since 1998, the Islamic Medical Association of Malaysia, another FIMA member, has raised public awareness on measures to combat HIV/AIDS. Its main achievement was the establishment of homes for women and children living with HIV/AIDS. 16 Family life and rejuvenating women's self-esteem and feeling of self-worth are the mainstay of this activity. Children receive medical care, family-life enviroment, and education. Abandoned and orphaned children affected with HIV/AIDS receive various medical, social, and educational care by dedicated experts.

Other activities were conducted in Pakistan, Indonesia, and other Asian countries. The Federation of Islamic Medical Associations is planning to strengthen and widen these activities to include more countries and communities.

\section{In the Middle East and North Africa}

In January 2006, FIMA launched its program Protection of Our Youth from Sexually Transmitted Infections and HIV/AIDS. ${ }^{6}$ Its aim is to raise the general public awareness based on training well-educated and dedicated local community workers/leaders who will continuously and professionally work in their respective sectors of society, especially with youth. 
The following is an update of this ongoing activity as of July 2008.

During the past two-and-a-half years, the program designed practical and well-constructed condensed courses suitable for everybody, irrespective of educational background. Twenty-eight teams were trained, each consisting of 25-30 local youth leaders, alternating male and female groups. To date, the program graduated 753 well-prepared workers in Jordan, Qatar, Bahrain, Sudan, Algeria, and Morocco. Government, charity, civil and social organizations discovered the value of this project and requested its widening and continuity. The program has invitations and memoranda of understanding to spread this activity to several countries of the region.

Trainees are volunteers from several sectors of society, including the following:

- Imams

- Social workers

- Educators, teachers

- Medical professionals

Trainees' qualifications consist of the following:

- University graduates

- Ready for voluntary work

- Interest in dealing with youth problems

- Ability to address the youth

- Ability to participate and lead in team work

Training course characteristics include the following:

- One full week, from 8 a.m. to 6 p.m.

- Comprehensive lectures

- Open discussions

- Case studies

- Printed materials and books

- Final workshop

- Open discussions

- FIMA certificates

The trainees receive systematic reviews on

- STIs and HIV/AIDS information on the infectious organisms and modes of infection

- International and local statistics

- Protection activities conducted worldwide

- Treatment and care of affected people worldwide

- International reactions and attitudes towards the problem

- Islamic teaching and guidance towards protection and management

- Islamic jurisprudence related to this issue

Graduates are also equipped with a wealth of educational materials, including the following:

- Recordings of updated scientific and epidemiologic knowledge

- Books published by qualified authors about various aspects of this issue

- References in Islamic guidance and jurisprudence

- Training in spiritual support

Graduates are requested to fulfill the following conditions: to give at least 10 lectures/presentations/seminars per year to the local youth at schools, colleges, camps, clubs, youth centers, or mosques.

Twenty-eight courses have been accomplished so far, with the following regional breakdown: 2 in Qatar, 4 in Bahrain, 16 in Jordan, 2 in Sudan, 2 in Algeria, and 2 in Morocco. All courses were held in cooperation with FIMA and local civil, social, cultural, and educational organizations. To date, 753 men and women have graduated.

Activities provided by graduates in their local communities are the following:

- 7000 lectures

- Four web sites

- 100 media presentations/interviews

- 50 newspaper/journal interviews

Near future plans are

- To graduate 1000 volunteers, ensuring 10,000 lectures/presentations annually

- Courses to prepare senior leaders/workers in various countries, to assume leadership to continue and develop this activity, and to function autonomously in their respective countries/communities

The Federation of Islamic Medical Associations, its member associations, collaborators, and concerned field workers remain eternally grateful to Almighty Allah dit for enabling them to pursue these dedicated efforts to serve Allah's creation in combating this world menace by using His guidance. 


\section{References}

1.UNAIDS and WHO. Understanding the latest estimates of the 2007 AIDS epidemic update. Last updated: November 2007. Available from http://data. unaids.org/pub/EPISlides/2007/071118_qa_method ology_backgrounder_en.pdf.

2. UNAIDS, World Health Organization. AIDS epidemic update. Geneva, Switzerland: UNAIDS and World Health Organization; 2007. Available from URL, http://data.unaids.org/pub/EPISlides/2007/2007_ep iupdate_en.pdf.

3. CDC. CDC HIV/AIDS Fact Sheet: A glance at the HIV/AIDS epidemic. Revised June 2007. Available from http://www.cdc.gov/hiv/resources/factsheets/PDF /At-A-Glance.pdf.

4. UNAIDS. 06 Report on the global AIDS epidemic: executive summary. A UNAIDS 10th anniversary special edition. Available from URL, http://data.unaids.org/pub/GlobalReport/2006/200 6_GR-ExecutiveSummary_en.pdf.

5. CDC: Sexually Transmitted Disease Surveillance 2005. Division of STD Prevention. November 2006. Available from URL, http://www.cdc.gov/std/stats 05/05pdf/Surv2005.pdf.

6. Al-Qudah AH, Misha'l A. Protection of our youth from STIs and HIV/AIDS A project implemented in the Middle East. FIMA Yearbook. 2007:123-8. Available from http://www.fimaweb.net/main

/fimayearbook/FIMA\%20Year\%20Book\%202007.pdf. 7. Fortenberry JD. Sexually transmitted disease in adolescents. Up to Date for Patients. Available from URL, http://www.uptodate.com/patients/content /topic.do?topicKey= XFz17xS4jwDxpF.

8. Kagimu M, Said K, Hogle J (editors). The Islamic approach to HIV/AIDS: enhancing the community response: what imams and mosque communities can do? Proceedings of the 3rd International Muslim Leaders' Consultations as HIV/AIDS in Addis Ababa, Ethiopia, 2007 July 23-27. Kampala, Uganda: The Islamic Medical Association of Uganda. Available from http://www.imau-uganda.org/WEB\%20link \%20files/What\%20Imams\%20and\%20Mosques\%20ca n\%20do.pdf.

9. Kagimu M. An update on the implementation of the Islamic approach to HIV/AIDS. FIMA Yearbook. 2007:101-22. Available from URL, http://www.fimaweb.net/main/fimayearbook/FIM A\%20Year\%20Book\%202007.pdf.

10. Ebrahim M, Nawab S. HIV/AIDS prevention: An Islamic perspective. Experience from South Africa. FIMA Yearbook. 2007:91-100. Available from URL, http://www.fimaweb.net/main/fimayearbook/FIM A\%20Year\%20Book\%202007.pdf.

11. Kasule $\mathrm{OH}$. A critique of the biomedical model from an Islamic perspective. FIMA Yearbook. 2003:83-94.

12. Badri M. Where we cautiously agree and where we disagree with the western campaign against AIDS. FIMA Yearbook. 2003:15-22.

13. Ebrahim AFM, Islam and HIV/AIDS FIMA Yearbook. 2007:1-16. Available from URL, http://www.fimaweb.net/main/fimayearbook/FIM A\%20Year\%20Book\%202007.pdf.

14. The World Health Organization. Dawr al-dīn wa al-akhlāqiyyāt fī al-wiqāya min al-aydz wa mukāfathih. Alexandria, Egypt: The World Health Organization-Eastern Mediterranean Regional Office, 1992. Available from http://www.emro.who. int/dsaf/dsa132.pdf.

15. Islamic Organization of Medical Sciences. The rulings arising from the discovery of AIDS. In: El-Gendy AR, Al-Awadi AR, editors. The international Islamic code for medical and health ethics. Kuwait: Islamic Organization of Medical Sciences; 2005. p. 366-75. Available from http://www.

islamctr.org/codepart3topic30.asp.

16. Nordin M. Rumah Solehah - Malaysia, Halfway home for women and children with HIV/AIDS. FIMA Yearbook. 2007:129-34. Available from URL, http://www.fimaweb.net/main/fimayearbook/FIM A\%20Year\%20Book\%202007.pdf. 